\title{
"Sit u hier maar gaan staan jy daar": Kantaantekeninge by Jakobus 2:1-4
}

\author{
Jan van der Watt \\ Departement Nuwe-Testamentiese Wetenskap \\ Universiteit van Pretoria
}

\begin{abstract}
"You may sit here, but you must stand there" -

On James 2:1-4

The question is what the speaker in James 2:2-3 intended when he said that the rich man may sit "here" on a good place, but that the poor man must stand over "there" or may sit "under" his footstool. It is argued that this episode should be located within a larger ancient house which was used as a gathering place for the Christian community. The poor man is asked to stand in the courtyard or may sit on the ground in the sittingroom. The rich man gets a place on the couches, common pieces of furniture in these rooms.
\end{abstract}

\section{INLEIDING}

Die boodskap van Jakobus 2:1-3 is duidelik - moenie onderskeid maak tussen mense op grond van ekonomiese of sosiale faktore wat dikwels op menslike vlak 'n rol speel nie. Skeer almal oor dieselfde kam. ${ }^{1}$ Tog verbaas dit 'n mens hoe onnoukeurig die kommentare dikwels hierdie pragtige teks hanteer. Dit is algemeen om te vind dat kornmentatore eenvoudig sê dat Jakobus 2:2-3 'n fiktiewe situasie beskryf van die ryk persoon wat 'n beter sitplek (wat dit ook al mag behels) as die arm man kry en so word daar teen die arm man gediskrimineer. Met hierdie opmerking wat 'n Graad 1 leerling ook uit die teks kan

\footnotetext{
1 Hierdie was 'n opdrag wat volgens wet vir die Jode gegeld het, soos uit Levitikus 19:15 blyk. Die gelyke hantering van jou naaste was 'n vereiste.
} 
aflees, is die saak dan afgehandel. Bitter min meer word gesê. ${ }^{2}$ Met so 'n bietjie eksperimentering wil ek graag probeer aantoon hoe die konkretisering van die voorbeeld uit Jakobus 2:2-3 tog die verstaan van die teks verryk.

Omdat my gewaardeerde kollega, professor Gert Pelser, altyd gesteld is op die noukeurige hantering van tekste, dra ek graag hierdie artikel aan hom op. Dit is my hoop dat hy nog veel vreugde sal vind uit die lees van die belangrikste teks van alle tekste.

Die vraag wat in hierdie artikel aan die orde gaan kom, is glad nie pretensieus nie en wil ook nie tot groot teologiese uitsprake lei nie. Daar gaan gevra word na die konkrete situasie waarin die ryke en die arme hulle waarskynlik kon bevind het en hoe die historiese gegewens die verstaan van die situasie verryk wat in die teks van Jakobus aangebied word. In die $\sin$ is hierdie artikel eksperimenteel en maak dus so 'n bietjie aanspraak op verbeeldingrykheid in die hantering van die min gegewens wat ons tot ons beskikking het om hierdie teksgedeelte uit die Nuwe Testament te interpreteer.

\section{DIE TEKS}

Hoewel die perikoop oor die eerste 13 verse van hoofstuk 2 strek, gaan net die eerste vier verse in detail aandag ontvang, aangesien die probleem wat in die artikel aangespreek gaan word, in hierdie vier verse voorkom.

\footnotetext{
${ }^{2}$ Kyk byvoorbeeld Pretorius (1988:ad loc.) of Wall (1997:111-114) wat andersins interessante opmerkings mak, maar nie sê waar die vergaderplek is of hoe dit uitsien nie. So ook Du Plessis (1993:ad loc.); Williams (1965); Hoppe (1989:52); Davids (1982:107-109); Sidebottom (1982:37-38); Maier en Holland (1988:44-48). Ten spyte van ' $n$ andersins deeglike bespreking gee Martin (1988:ad loc.) ook nie hieraan aandag nie. Mußner (1981:118) beweer dat die beskikbare inligting oor hierdie saak te min is om ' $n$ mens daaroor uit te laat.
} 
Jakobus 2:1-4 is goed gestruktureer:

A

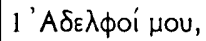

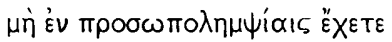

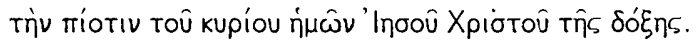

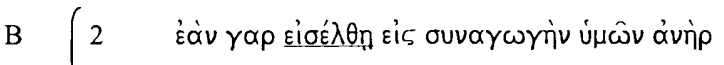
хрибoбaktúos

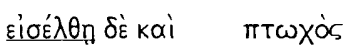

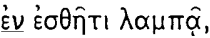

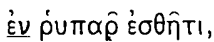
B $^{\prime} \quad \int 3 \quad \dot{\varepsilon} \pi ı \beta \lambda \dot{\varepsilon} \psi \eta \eta \varepsilon \dot{\delta}$

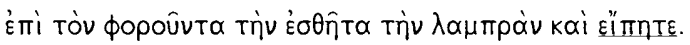

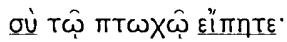

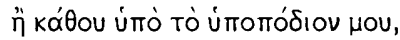

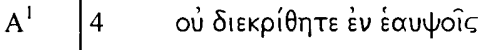

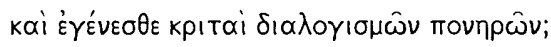

Blokke $\mathrm{A}$ en $\mathrm{A}^{1}$ dra die boodskap van die gedeelte in reële terme oor. A bevat 'n imperatief - die geloof in Jesus moet nie met die anneming van persone gepaard gaan nie. $A$ ' is ' $n$ retoriese vraag wat dus ook op ' $n$ stelling neerkom - as die gemeentelede doen wat in $\mathrm{B}$ en $\mathrm{B}^{\prime}$ beskryf word, het hulle soos regters met 'n slegte oordeel geword. Hulle het hulle eie kriteria gestel bo die kriteria wat die geloof in Jesus vereis - die

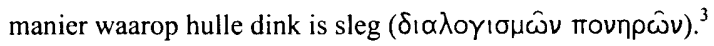

\footnotetext{
${ }^{3}$ Een van die grondtrekke van die denke in hierdie brief is die oriëntering van die mens se denke, oftewel sy soeke na wysheid. In Jak 3:13-18 word die kontras tussen goddelike en menslike wysheid (lewenstyl) geskets. Die gelowige moet dus soos Jesus begin dink en doen en nie soos mense nie. Die gedagte is ook grondliggend aan die opdrag in 2:1 en die retoriese vraag in 2:4.
} 
Die twee blokke wat B en B' gemerk is, skets 'n waarskynlik hipotetiese situasie om die verkeerde manier te illustreer waarop daar tussen mense onderskeid gemaak word. Uit hierdie illustrasie moet gesien kan word hoe verkeerd dit is om in Christelike konteks onderskeid tussen persone te maak. Retories word die imperatief (2:1) en die antwoord op die retoriese vraag $(2: 4)$ deur hierdie illustrasie gedra. Daar moet by die leser geen twyfel meer wees dat 'n Christen nie onderskeid tussen mense mag mak nie, anders word hy of sy 'n swak en slegte beoordelaar. Hoewel die illustrasie dus denkbeeldig mag wees, kan dit nie te ver van die realiteit in die gemeente af staan nie, anders sou die retoriese en kommunikatiewe krag daarvan grootliks verlore wees. ${ }^{4}$

B skets op parallelle wyse die onderskeid tussen die twee persone wat daar

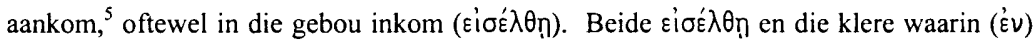
hulle getooi is, word ook op parallelle wyse gekontrasteer. Die basis van die kontras rus op ekonomiese onderskeid - ryk en arm - soos dit uit die twee persone se klere na vore kom. Dit is ook meer as bekend dat rykdom en sosiale status in die antieke wêreld karperde was. ${ }^{6}$ Die kleredrag weerspieël dus ook 'n sosiale en derhalwe 'n magsonderskeid.

In $\mathrm{B}^{1}$ word die parallel voortgesit in die reaksie op die aankomelinge deur aan te dui wat vir elkeen gesê word ( $\varepsilon і ̈ \Pi \eta T \varepsilon)$. Uit hierdie reaksie blyk die verkeerde oordeel wat aan die dag gelê word. Daar word verskillende plekke aan die verskillende persone toegesê. Dit is duidelik dat 'n plek hier nie maar net 'n plek is nie. In 2:6 word daar pertinent gesê dat die arm man oneer aangedoen is deur die onderskeid in plekke wat

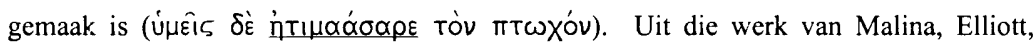

\footnotetext{
4 Daar bestaan verskil in mening oor die hipotetiese aard al dan nie van hierdie illustrasie in verse 2-3, veral as die kondisionele éàv yá $\rho$ in ag geneem word. Kyk Felder (1982-83:53); Davids (1982:107). Soos bo genoem, is dit waarskynlik hipoteties, maar nie totaal denkbeeldig in die sin dat dit niks met die gemeente te doen het nie en dat hulle hulle nie daarmee sou kon assosieer nie. Ter wille van die kommunikasie moes die illustrasie aan die senuweepunte van die gemeente raak. Pretorius (1988:ad loc.); Polhill (1986:396); Felder (1982:91); Cedar (1984:54); Smelik (1960:46); Reike (1964:27); Mußner (1981:116-117), Grünzweig (1978:69), Hoppe (1989:52), Penner (1996:270) en Maynard-Reid (1987:52) is ewe-eens die mening toegedaan dat hierdie 'n hipotetiese, maar realistiese voorbeeld is. Martin (1988:ad loc.) verskil egter: "It is better, however, to understand vv 2.3 as depicting a familiar scene, which is implied by the use of the indicative mood in what follows". So ook Wall (1997:103).

5 Vir 'n bespreking of die persone lede van die gemeente was, sien Boggen (1982:261).

${ }^{6}$ Grosheide (1970:32).
} 
Rohrbaugh, Neyrey ${ }^{7}$ en ander weet ons dat eer en skaamte in die antieke wêreld 'n prominente en selfs dominante rol gespeel het. Dit het in 'n groot mate die sosiale ordening gereël. Waarom dit dus hier gaan is 'n ernstige ingrype op die persoon van die arm man. Die feit dat dit as illustasie gebruik word vir die absoluut verkeerde, degraderende manier waarop een mens ' $n$ ander hanteer, beklemtoon dat die onderskeid in plekke wat gemaak is, ingrypende sosiale implikasies gehad het. Die vraag wat verder in hierdie artikel aandag gaan ontvang, is wat die onderskeid tussen die plekke is wat aangewys is. Hoe moet ons ons dit voorstel?

\section{WAAR IS "HIER" EN WAAR IS "DAAR"?}

Die probleem ontstaan as daar aan die ryk man gesê word dat hy hier op die goeie of

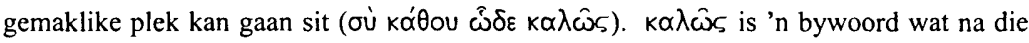
wyse van sit of na die aard van die sitplek kan verwys. ${ }^{8} \hat{\omega} \delta \varepsilon$ dui op 'n plek naby die persoon wat die plekke uitdeel. ${ }^{9}$ Dit dui oënskynlik op die plekke met die hoër status indien die konteks van die gedeelte in gedagte gehou word.

Daarteenoor word daar aan die arm man gesê dat hy "daar" (દંKદî) moet gaan staan

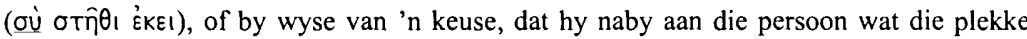

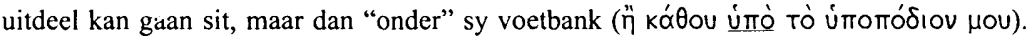
Uit die konteks is dit duidelik dat beide die posisies plekke is wat die arm man oneer aandoen.

- Die eerste opsie, naamlik dat die man "daar" kan gaan staan, staan in direkte kontras met die ryke wat "hier" kan kom sit. Die afstand van die persoon wat die plekke uitdeel word beklemtoon: غ̇kEı dui op 'n ver afstand van die persoon af wat die plekke uitdeel. ${ }^{10}$ 'n Vraag is dus wat die afstand van die persoon wat die plekke uitdeel met die saak te doen het.

\footnotetext{
${ }^{7}$ Kyk onder andere Neyrey (1998); Malina en Rohrbaugh (1992).

8 In sommige vertalings, bv RSV, word dit met “asseblief" weergegee.

9 Louw en Nida (1988, 1989:ad loc.) beskryf die gebruik van $\omega \delta \varepsilon$ so: "a position relatively near the speaker, writer, or viewpoint person - "here."

${ }^{10}$ Louw en Nida (1988, 1989: ad loc.) beskryf die gebruik van Éčl so: " a position relatively far from the speaker, writer, or viewpoint person - "there, at that place." Kyk ook Adamson (1976:107).
} 
- Met die tweede opsie, naamlik dat die arm man onder by sy voetstoel kan gaan sit, is die probleem nie die afstand van die persoon af wat die sitplek toeken nie, maar die aard van die sitplek. Die ryke het 'n k $\alpha \lambda \omega \hat{s}$ (eervolle) sitplek gekry; die arme

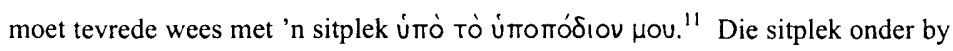
die voetbank word dus as minderwaardig teenoor die sitplek van die ryke gestel. Vyande word soms daar gevind om hulle posisie van vernedering aan te dui. ${ }^{12}$ Daar moet op gelet word dat die persoon nie uitgenooi word om "op" ( $\dot{\varepsilon} \pi i)$ die voetbank te sit nie, maar "by" of "onder" (ứó), wat verstaan moet word as op die grond voor of langs die voetbank, ${ }^{13}$ soos die NIV dit ook vertaal. ${ }^{14}$

Watter soort van bymekaarkomplek moet 'n mens jou voorstel waar die opsies wat hierbo genoem is, moontlik is?

\section{4. 'N SINAGOGE OF NIE?}

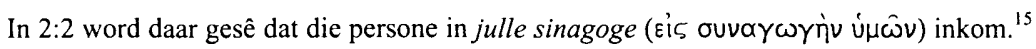
'n Eerste reaksie is om af te lei dat dit inderdaad hier om 'n Joodse sinagoge as letterlike gebou gaan ${ }^{16}$ - dit is tog welbekend dat die vroeë Christene nog vir 'n afsienbare tyd in

\footnotetext{
"Kyk Adamson (1976:109) vir meer inligting oor die voetstoel.

12 Wall (1997:113); Davids (1982:109); Schnider (1987:57).

${ }^{13}$ Sien Pretorius (1988:ad loc.); Schnider (1987:57-58).

14 Hoe 'n mens die Ou Afrikaanse vertaling (1933) moet verstaan is vir my 'n raaisel: "... of hier onder my voetbank sit". Die Nuwe Afrikaanse vertaling vertaal beter: "Kom sit hier by my voete". Die gedagte van die voetbank word dus uit die vertaling gelaat. Die vraag, soos later ook sal blyk, of dit regtig by die persoon se voete was. Sy voete is waarskynlik op 'n bank getel, tensy 'n stoel met 'n voetbank gebruik is, wat ook 'n moontlikheid was.

15 Pretorius (1988:ad loc.) wissel in sy beskrywing van "sinagoge" hier - hy praat van "plek van aanbidding" en dan weer van die "gemeentebyeenkoms". Die NEB vertaal met "your place of worship"; die KJV, RSV en NASB met "your assembly"; die NIV met "your meeting". Dit dui op die onsekerheid

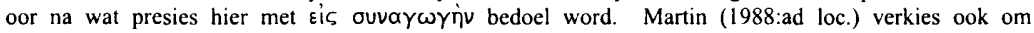
"sinagoge" as "the meeting" en Wall $(1997: 104,111)$ om dit as "a gathering of believers" te lees. Kyk ook Penner (1996:269).

${ }^{16}$ Kyk Maynard-Reid (1987:55); Vyhmeister (1995:275). Davids (1982) stel die moontliheid dat dit om 'n gebou gaan, maar kies self daarvoor dat sinagoge hier op die byeenkoms dui. Kyk ook Mußner (1981:117); Schnider (1987:57).
} 
sinagoges ontmoet het. ${ }^{17}$ Die posisies waarna verwys word, naamlik die "hier" en "daar" of die "staan" of "sitplek", moet dus binne die konteks van die sinagoge gesoek word. Interessant genoeg is die meeste kommentare wat hierdie keuse uitoefen, ietwat vaag oor waar die "hier" of "daar" presies is. Die oplossing wat voorgestaan word, is dat dit uit die argeologiese opgrawings blyk dat daar bankies soos trappies langs die mure was, wat die sinagoge amper soos 'n arena gemaak het. Dit kan duidelik uit figuur 1 (Addendum) gesien word. Die argument is dus dat die hoër plekke die beter plekke was en dat die onderste trap of selfs die grond voor die trap die plek was wat aan die arm man toegesê is. $^{18}$

Die swakplek in die argument is dat daar nie met die $\hat{\omega} \delta \varepsilon$ of die $\dot{\varepsilon} K \varepsilon \mid$ rekening gehou word nie. Die bankies (trappies) loop tog parallel met die muur in die rigting van die podium waarvandaan daar uit die Tora gelees is, wat natuurlik die eervolste plek in die gehou was. Wat $\hat{\omega} \delta \varepsilon$ en $\varepsilon k \varepsilon \mid$ betref - lui die verklaring van die voorstanders van die standpunt dat dit om die singagoge gaan, dan - is dat hoe nader 'n mens aan die podium gesit het waar die voorlesing vandaan gedoen is, hoe eervoller was die plek. Wat egter hier besef moet word, is dat dit sou beteken dat daar meer of minder eervolle plekke op die grond asook op die hoër trappies moes gewees het. Die teks impliseer so iets nie.

'n Verdere probleem is wat met die staanplek waarheen die arm man verwys is, bedoel word. Daar was waarskynlik staanplek in die singagoge. Maar weer eens geld dieselfde argument. Die staanplek naby die podium waar die wet voorgelees is, sou meer eervol wees as die sitplek wat verder daarvan geleë was. Dit beteken ook dat as die arm man gevra is om by die stoel van die voorsitter by die podium op die grond te kom sit, hy eintlik ook 'n eervoller plek sou gehad het as wat iemand sou hê wat verder terug op die trappies teen die mure sou sit. Dit lyk dus onwaarskynlik of hier van 'n sinagoge sprake is, soos ons dit argeologies ken.

\footnotetext{
${ }^{17}$ Grosheide (1970:32) maak heelwat daarvan dat in 5:14 die woord ÉkK $\lambda$ пoía vir kerk gebruik word. Kyk ook Davids (1982:108). Die woord word egter in 'n ander konteks gebruik - in 5:14 word daar van die ouderlinge van die kerk gepraat, terwyl daar in 2:2 van die byeenkoms sprake is. Dit verswak sy argument aansienlik.

18 Kyk Gispen et al (1997:ad loc.) en Grosheide (1970:33) wat impliseer dat die arm man ondertoe op die trappies in die sinagoge moes sit.
} 


\section{MOONTLIK'N HUIS?}

Die ander moontlikheid is dat hier van 'n huis sprake is waarin die Christene byeengekom het. Dit is ' $n$ bekende feit dat die vroeë Christene huise as bymekaarkomplekke benut het, veral nadat verhoudings met die Jode in die sinagoges versuur het. ${ }^{19}$ Wat hierdie 'n reële moontlikheid makk, is dat die woord "sinagoge" nie noodwendig vir 'n gebou gebruik word nie, maar ook op die geleentheid van die byeenkoms of vergadering van mense, gewoonlik met religieuse oogmerke, ${ }^{20}$ kan dui. ${ }^{21}$ Pretorius (1988:ad loc.) maak die opmerking dat dit in die vroeg-Christelike konteks nie gebruiklik was om die woord vir die vergaderplek te gebruik nie. Dit maak dit moontlik om 'n huis as byeenkomsplek te oorweeg sonder om teen die betekenis of gebruik van sinagoge in te gaan. .Die woord sinagoge kan inderdaad vir so 'n situasie ook gebruik word. ${ }^{22}$ Die

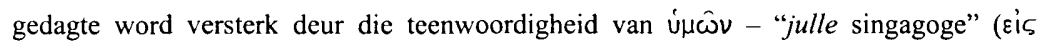

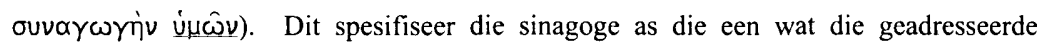
Christene s'n is. Christene wys ook oënskynlik plek aan. ${ }^{23}$ Dit is moontlik dat hulle dit met Jode kon deel, maar die stelwyse hier lyk of dit die gedagte bevoordeel dat dit spesifiek net die gelowiges se byeenkoms is wat bedoel word; daarom word die "julle" hier gebruik. Dit blyk dus dat "sinagoge" 'n idiomatiese uitdrukking vir die Christelike

19 Dit het naturlik nie oral ewe vinning gebeur nie. Baie het van plaaslike omstandighede afgehang. Davids (1982:108) is dus reg dat die skeiding nie as noodwendigheid gesien hoef te word nie.

20 Die woord sinagoge kan ook op 'n algemene byeenkoms dui, maar in die Bybelse konteks is die byeenkoms gewoonlik religieus bepaald - kyk Feinberg (1998:ad loc.). Martin (1988:ad loc.) laat met die

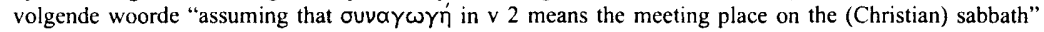
ruimte oop dat die woord "sinagoge" op enige ontmoetingsplek van die gelowiges en dus ook 'n huis kon dui. Die vraag of dit nie eerder na 'n hofsaal of juridiese vergadering moet verwys nie, word nie hier bespreek nie - kyk Ward (1969:94); Penner (1996:269-271); Wall (1997:104-111). Omdat die aard van die byeenkoms nie bepalend is vir die aard van die gebou wat gebruik is nie, sou dit nie verskil maak as dit eerder hier om 'n byeenkoms met die oog op 'n hofsaak as met die oog op ' $n$ godsdienstige byeenkoms in die gemeente gegaan het nie. Kyk ook Smit (1990:64).

21 So Pretorius (1988:ad loc.). Sien ook Du Plessis (1993:ad loc.); Maier en Holland (1988:46). Feinberg (1998:ad loc.) laat die moontlikheid oop dat dit na die gebou kan verwys waar religieuse byeenkomste gehou is. Kee (1995) het in sy artikel aangedui dat 'n mens nie sonder meer kan aanvaar dat "sinagoge" hier na 'n ontmoetingsplek verwys asof daar vaste geïnstitusionaliseerde godsdiens beoefen word nie. Sien ook Adamson (1976:105).

\footnotetext{
22 Dibelius (1964:167).

${ }^{23}$ Kyk Grosheide (1970:33); Schlatter (1956:166); Dibelius (1964:165).
} 
bymekaarkoms is - mense wat met die Jodedom vertroud is of uit Judea kom, het voortgegaan om hulle vergaderinge "sinagoges" te noem. ${ }^{24}$

Hierdie aanvanklike opmerkings maak dit dus 'n moontlikheid om 'n huis as locus vir die voorbeeld in Jakobus 2:2-3 te neem. Die vraag is of die gegewens wat bekend is oor antieke huise 'n aanvaarbare en goeie verklaringsbasis bied vir die situasie wat in die teks beskryf word. Die eerste vraag is of daar gegewens is wat daarop dui dat voetbanke in antieke huise aangetref word. Die algemene is om van ' $n$ voetbank by ' $n$ troon te praat. Indien daar nie bewyse is dat daar wel voetbanke in woonhuise was nie, sou dit die moontlikheid van 'n huis uitsluit, aangesien die voetbank pertinent genoem word.

Uit figure 2 en 3 (Addendum) is dit duidelik dat daar wel voetbanke in huise aangetref is, oënskynlik meer in groter huise ("mansions"). Sover ek kon vasstel, is voetbank by twee soorte meublement gebruik - die een is by 'n lêbank wat in 'n sitkamer gebruik is waarop twee persone kon lê (figuur 2 - Addendum) ${ }^{25}$ Die voetbank moes dan waarskynlik onder andere gebruik gewees het as 'n soort van 'n trap. Dit kan uit die voorstelling gesien word. Die ander tipe voetstoel is by 'n enkelstoel - die figuur met die vrou toon duidelik dat sy op 'n soort rottangstoel sit en dat haar voete op 'n voetbank rus (figuur 3 - Addendum). ${ }^{26}$ In hierdie geval is dit meer in 'n privaat situasie waar sy besig is met versorging van haarself. Dit laat my vermoed dat die bank waarop twee mense kon sit en wat vir 'n sitkamer bedoel is, die meer waarskynlike opsie sou wees - dit ten

\footnotetext{
${ }^{24}$ Grosheide (1970:33). Williams (1965:111) praat van "phraseology" wat deur die Christene by die Jode oorgeneem is. Schlatter (1956:167) beweer dat dit inderdaad hier om Joodse Christene gaan wat nog dieselfde terme as die Jode gebruik. Kyk ook Maier en Holland (1988:46). Dibelius (1964:166) stel dit

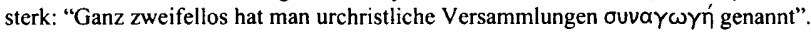

2s Soos Dibelius (1964:165) sê: "Von Grabmälern und anderen Monumenten kennen wir auch den Fußschemel im Hausgebrauch."

26 Daar word verskeie kere na "voetbank" in die Bybel verwys, feitlik deurgaans na die voetbank van 'n troon (dus 'n enkele stoel - vgl. Jes 66:1; Ps 110:1; Mat 5:35; 22:44; Mk 12:36; Luk 20:43; Hand 2:35; $7: 49$; Heb. $1: 13 ; 10: 13$ ). God, as die een wat in die hemel op 'n troon sit, het die aarde as sy voetbank. As Jesus saam met Hom aan sy regterhand sit, word die vyande van Jesus die voetbank van sy voete gemaak. Dat die voetbank 'n plek van oneer in verhouding tot die persoon wat op die troon of stoel sit, was, blyk uit gedeeltes soos Heb 1:13 waar die voetbank gebruik word om Jesus se eervolle posisie teenoor sy vyande te illustreer. Schlatter (1956:166) het ook die gedagte geopper dat dit hier om 'n soort "stoel" gaan. Dibelius (1964:165) meen ook dat die enkelvoud $\mu$ ov op ' $n$ enkelstoel kan dui. Hy meen egter dat dit ondenkbaar is dat daar sulke stoele in die gemeente was. Daarom wil hy die gedagte van die "voetstoel" bloot sien as "auf den Boden".
} 


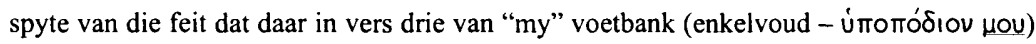
gepraat word. Dit individualisering van die voetbank hoef nie ongewoon te wees as dit by 'n bank pas waar daar twee mense by gesit het nie - dit is eintlik te wagte. Neem byvoorbeeld iemand wat by 'n tafel saam met ander by 'n troue deel - hy sou kon sê: "Kom maak 'n draai by my tafel" sonder om daarmee te ontken dat daar ander mense ook

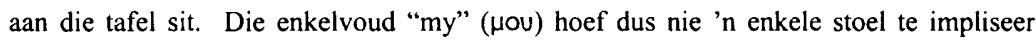
nie. $^{27}$

Daar was dus voetbanke in huise wat dit te verstane maak dat hier moontlik na 'n sitkamer verwys word. Waarna sou die "daar" ('̇KEI) binne die konteks van 'n huis dan kon verwys? Daar moet op gelet word dat die غ̇kє। spesifiek met "staan" verbind word

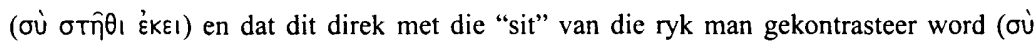

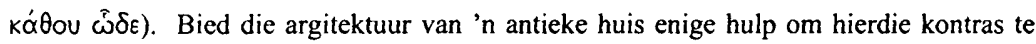
verstaan?

Indien na die tipiese argitektuur van antieke huise gekyk word, val dit allereers op dat daar verskillende soorte huise was na gelang die ekonomiese posisie asook die individuele smaak van die mense gewissel het. ${ }^{28}$ Een argitektoniese eienskap was egter baie algemeen. Feitlik alle huise was om 'n binneplein gebou: "The courtyard is the most characteristic architectual feature of Palestinian dwellings, an integral part of the house". ${ }^{29}$ Wat belangrik is om op te let, is dat die binneplein as integrale deel van die huis gesien is. Dit is benut as deel van die huis: "The courtyard is in effect the house's external dimension of which every square centimetre is highly prized". ${ }^{30}$

Daar was eenkamer huise (vir so 2-4 persone) wat omtrent so groot soos 'n hedendaagse motorhuis was. Grothuise wat uit een of twee kamers bestaan het, was ook

\footnotetext{
${ }^{27}$ Laws (1980:100) beweer sonder bewyse dat ' $n$ voetstoel aan die president van die sinagoge verskaf is. Die arm man sou dan daar kon gaan sit. Daar is geen getuienis dat daar 'n spesiale stoel vir die "president" van die Christelike byeenkoms was nie en verder kan daar gevra word waarom hy juis daar en nie op 'n ander plek op die grond moes gaan sit nie. Dit vernedering - wat die gedeelte juis wil kommunikeer - sou groter gewees het as hy nie by die belangrikste stoel van die president moes gaan sit nie, maar iewers anders. Die voorstel van Laws lyk dus verdag.

28 Kyk Botha (1998:39) oor die probleem van veralgemening as dit by die argitektuur van antieke huise kom. Feitlik in elke huis is die wense van die eienaar duidelik uit te ken. Kyk Botha (1998:43).

29 Kyk Botha (1998:44 en 40) wat ook aantoon dat die eienskap van 'n binneplein beide vir Romeinse huise as vir die huise in Palestina gegeld het. Kyk ook Rousseau en Arav (1996:129).

${ }^{30}$ Botha (1998:44).
} 
as wonings gebruik. "Trosbehuising", waar verskeie families 'n kamer of kamers rondom 'n gemeenskaplike binneplein besit het, was ook algemeen. Groot plaaskomplekse was ook 'n algemene gesig. ${ }^{31}$ Dan was daar die groter huise ("mansions") wat 'n groter tipe gebou rondom 'n binneplein was. Hierdie soort huise was nie so algemeen in Palestina nie, maar het wel meer in die ander stede van die Romeinse Ryk voorgekom. Die mooi strukture is onder andere met die oog op sosiale kontak gebou. Soos uit figure 4-6 (Addendum) blyk, is daar 'n sitkamer aan die binneplein gebou. Die twee is met 'n deur verbind. As jy in die binneplein staan, sou jy kon sien en hoor wat in die sitkamer aangaan. Daar was ook nie onder normale omstandighede stoele of sitplek in die binnehof nie.

\section{6. 'N SUGGESTIE OOR WAAR "DAAR" IS.}

Ek sou dus wou suggereer dat so 'n huis die situasie is wat Jakobus 2:2-3 in die oog het. Veronderstel dat die twee mans, soos Jakobus dit beskryf, stap in 'n huis ("mansion") 32 in waar die Christene bymekaar is. ${ }^{33}$ Dit was die voorreg van die huisheer - wat waarskynlik ook die leier van die groepie Christene kon wees ${ }^{34}$ - om plekke aan te wys.

\footnotetext{
${ }^{31}$ Vir 'n meer gedetailleerde bespreking van die huise in die antieke tyd, kyk die goeie artikel van Botha (1998). Kyk ook Connolly en Dodge (1998); Bühlmann (1987); Rousseau en Arav (1996:128-131), asook 'n reeks bronne wat deur Botha (1998) genoem word. Al die inligting word nie hier herhaal nie.

32 Botha (1998:67) toon oortuigend aan dat daar dikwels in die evangelies na groter huise verwys word. Rousseau en Arav (1996:130) argumenteer ook dat van Jesus se dissipels groter huise moes gehad het.

33 Botha (1998:56) voer aan dat die groter huise met die oog op groter publieke gebruik ontwerp is. "In that society it was the only place where friends, clients, relatives and protégés could meet and talk." Dit is miskien te sterk gestel, maar beklemtoon tog die ideale moontlikheid wat groter huise vir die byeenkoms van die gemeente gebied het.
}

34 Pretorius (1988:ad loc.) meen dat die voorbeeld waarskynlik aan die leiers van die gemeente gerig is. "Dat 'n vergadering van die gemeentelike bestuur bedoel word, word deur sommige daarvan afgelei dat die aanwesiges, anders as by ' $n$ gemeentelike byeenkoms, spesiaal ontvang en aan hulle plekke toegewys word (v 3)." Die stelling staan nie op vaste bene nie, aangesien dit destyds 'n gebruik was om aan mense plekke toe te sê as hulle by jou aan huis kom, veral as hulle by jou kom eet (kyk Luk 14:7 waar die plekke by die bruilof gereël word). Daar moet nie aan groot getalle mense gedink word nie, wat so 'n reëling natuurlik moontlik en maklik maak. Die gelykenis van persone wat na agterste sitplekke gestuur is, terwyl hulle self by die bruilof voor gaan sit het (Luk 14:7), sinspeel op diè gebruik dat die leier of huisheer tog die gesag gehad het om oor die plekke te besluit. Dit mag ook wees dat hierdie leier waarvan hier sprake is, die parallel of ekwivalent van die leier van die Joodse sinagoge kon wees, met ander woorde dat sekere reste van die Joodse situasie in die Christelike situasie sigbaar is. Kyk Setzer (1992:ad loc.) oor die leiers van die sinagoge en Maier en Holland (1988:47) en Adamson (1976:105) oor die leier in hierdie gedeelte. 
Hy staan in die sitkamer en sê vir die rykman: "Sit u hier op die lekker plek". ${ }^{35}$ Dit sou waarskynlik na die banke in die sitkamer verwys waarop die persone twee-twee gelê het - dit is die normale maar ook die beste plekke. ${ }^{36}$

Nou wend die huisheer hom na die arm man met die woorde dat hy "daar moet gaan staan." Die daar dui daarop dat dit weg is van die kamer waar die huisheer op die oomblik is. As die argitektuur van die huis in ag geneem word, kan dit maar net die binneplein beteken. ${ }^{37}$ Daarom moet die arm man ook daar gaan staan. Daar is nie sitplek of banke nie. Deur die deur van die sitkamer kan die arm man dan sien en hoor wat aangaan, want die sitkamer (asook ander kamers) het in die groter huise op die binneplein uitgeloop (kyk figuur 4 - Addendum). ${ }^{38}$ Dit sou ook nie vreemd wees dat die persoon vir die arm man vra om daar te gaan staan nie, want die binneplein is as integrale deel van die huis gereken. Dit is nie asof hy die persoon uit die huis uitjaag nie. Wat die posisie wel degradeer, is dat die binneplein nie as die hoër geagte terrein van die huis (soos die sitkamer) gereken is nie ${ }^{39}$ en dat dit natuurlik verder weg was van die belangrike persone. Dit hou besliste sosiale statusimplikasies vir die arm man in.

Die tweede opsie wat die arm man gebied word, is om onder by die spreker ( $\mu \circ \mathrm{v})$ se voetstoel te gaan sit. Hy word wel in die vertrek toegelaat en inderdaad naby die

35 Dat daar belangriker en onbelangriker (ofte wel beter en slegter plekke) was, blyk onder andere uit die gelykenis in Lukas 14:7-14 van die mense wat by 'n bruilof aankom en dan voor gaan sit. Hulle word agtertoe gestuur en verloor so waardigheid. Die omgekeerde moet eerder plaasvind - as die persoon na ' $n$ beter plek genooi word, sal sy eer dienooreenkomstig styg. Kyk ook Matteus 23:6; Markus 12:39; Lukas 11:43 en Lukas 20:46 waar daar ook van die beter plekke sprake is. Kyk ook Vyhmeister (1995:278-280) vir 'n bespreking van die verband tussen sitplekke en status in die antieke tyd.

${ }^{36}$ Daar bestaan nie getuienis dat Christene spesiale soorte sitplek wat van die normale bekende sitplekke in daardie tyd verskil het, vir hulle byeenkomte gebruik het nie. Daarom is die mees aanvaarbare manier om met die gegewens te werk om te veronderstel dat hulle maar van die bestaande meubels in die huis gebruik gemaak het. Wat wel blyk, is dat htlle die kamers vol gepak het en dat daar op die grond (soos hier in Jak 2) en selfs op die vensterbanke (soos met Eutigus in Hand 20:9) mense gesit het indien dit nodig was.

${ }^{37}$ Phifer (1982:281) verwys na Easton wat beweer dat die "daar" beteken dat die persoon eenkant teen die muur moet gaan staan. Sy senario is dat die leier lekker op 'n stoel sit met sy voete wat op 'n voetbank rus. Die rekonstruksie klink baie soos 'n byeenkoms in 'n moderne huis. As daar na die antieke rangskikking van die meubels gekyk word, is daar nie eintlik 'n plek teen die muur nie. Verder moet die vraag gevra word waarom die persoon nie teen die muur kan gaan sit as hy op ' $n$ ander plek in die vertrek mag sit nie.

38 Kyk Botha (1998:64).

${ }^{39}$ Kyk Botha (1998:44-45). Die diere of hout vir die winter is ook dikwels in die binneplein gehou. 
huisheer, maar moet op die grond - nie eers op die voetstoel nie ${ }^{40}$ - gaan sit. Terwyl die ryke $k \propto \lambda \omega \hat{s}$ sit, word die arm man gedegradeer om op die grond te gaan sit. ${ }^{41}$ Dit is 'n duidelike onderskeid.

Daar moet tog op gelet word dat sekere diasporasinagoges wat opgegrawe is, min of meer dieselfde scenario toelaat. Sommige van die sinagoges het ook 'n aangrensende binneplein gehad, ${ }^{42}$ terwyl daar tekens was dat sekere van die sinagoges, byvoorbeeld by Dura Europas en Priene (beide eers 3-4 eeu nC) eers ook ou huise was wat toe omskep is in sinagoges. Hulle het dus kamers gehad wat aan die sinagoge gegrens het. Daar is ook tekens van voorportale wat na die groter saal gelei het. Dit lyk ook of die Oudstes banke gehad het waarop hulle gesit het. ${ }^{43}$ Dit sou ook goedskiks kon wees dat die gebou wel 'n sinagoge was, maar dan een soos in Dura Europas waar daar 'n aangrensende binneplein was. Twee faktore bevoordeel tog die gedagte dat dit eerder ' $n$ huis was, naamlik (i) die verwysing na 'n voetstoel - daar is geen teken dat die banke van die oudstes voetstoele gehad het nie; (ii) die Christelike aard van die verhaal - die Christene is in beheer en wys plekke aan. Dit sou of moes beteken dat die Christene die sinagoge oorgeneem het, of dat dit hulle eie gebou was. Gesien die sosio-ekonomiese situasie van die gemeente aan wie Jakobus skryf, is dit onwaarskynlik dat hulle in die eerste eeu al so 'n spesiale gebou gehad het wat net vir aanbidding ingerig is. Dit is meer as bekend dat hulle in huise bymekaar gekom het. Daarom sou ek steeds wou suggereer dat dit hier om 'n groterige huis (van een van die gemeentelede) gaan.

\footnotetext{
40 Vergelyk die argument vroeër oor ė

41 Die vraag waarom hy nie toegelaat is om op die voetstoel te gaan sit nie, is natuurlik nie regtig te beantwoord nie. Uit die meegaande figuur lyk dit asof die voetstoel met materiaal oorgetrek is. Sou dit kon wees dat die huisheer bang was dat die materiaal vuil sou word? Dit is sommer 'n "tong in die kies" opmerking, maar indien daar na die woord $\pi \tau \omega x$ 's gekyk word waarmee die arm man aangedui word, is dit miskien nie so vergesog nie - die woord kan daarop dui dat hy in vodde geklee was.

42 "Dura Europas had two entrances leading from the courtyard to the assembly hall" (Hachlili 1992:ad loc.). Twee sinagoges is daar opgegrawe, maar beide dateer uit die derde eeu, wat die getuienis 'n bietjie laat mak vir oorweging in 'n argument oor die eerste eeu.

${ }^{43}$ Hachlili (1992:ad loc.).
} 


\section{7. 'N "DAAR" EN 'N "HIER" KAN GROOT VERSKIL MAAK}

Uit Jakobus 2:6 is dit duidelik dat hierdie onderskeid wat gemaak word, die arm man

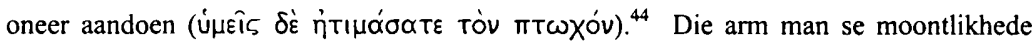
word in beide gevalle met die rykman gekontrasteer: "hier" staan teenoor "daar" en $k \alpha \lambda \hat{\omega} s$ staan teenoor "die sit op die grond". Sosiaal word daar dus gekommunikeer dat die arm man minderwaardig is. Normaalweg kan daarvan uitgegaan word dat die meer eervolle plek die plek nader aan die huisheer of die leier van die gemeente is. ${ }^{45}$ Die arm man wat buite in die binneplein moet gaan staan, word so afstandsgewys van die eervolle plek af wegbeweeg. Dat dit sosiale onderskeid beteken is duidelik. As die man 'n plek in die kamer aangebied word, is dit op die grond. Die degradering daarvan spreek ook vanself, veral as daar nog plekke op die banke oop was - dit word wel nie in die teks gesê nie, maar tog gesuggereer deur die feit dat die rykman so 'n lekker sitplek gekry het. Die konvensie van wat (sosiaal) goeie en wat slegte sitplekke was, is dus grondliggend aan die kommunikasie van die boodskap.

Die probleem hier is dus die sosiale aantasting van die arme bloot op grond van sy kleredrag $^{46}$ en dit in 'n openbare plek $^{47}$ soos die byeenkoms van die gemeente. Die plekke wat toegeken is, het die sosiale waarde van die persoon aangedui en op die wyse is

\footnotetext{
${ }^{44}$ Die beskrywing van wat die rykes met die gemeentelede doen, is interessant (Jak 2:6-7): "Is dit nie die rykes deur wie julle uitgebuit word nie, en is dit nie hulle deur wie julle voor die hof gesleep word nie? Is dit nie hulle wat die goeie Naam skend van Hom aan wie julle behoort nie?" Binne die sosiale konteks van die antieke wêreld dui dit op sosiale afstand. Hulle staan nie eers in 'n patronatus verhouding met die gelowiges nie. Inteendeel, as hulle hulle uitbuit en hof toe neem, impliseer dit dat daar van die kant van die rykes geen familie of vriendskapsbande met die gemeente bestaan nie. Die gemeente is nie "hulle" mense nie. Binne die sterk groepsgeörienteerde gemeenskap van destyds kommunikeer hierdie gedrag baie duidelik negatief en sosiaal afwysend. Die ironie is dat hierdie mense nou juis deur die gemeente so goed behandel word, terwyl die regtig belangrike mense - die besitters van die koninkryk (Jak 2:5) - volgens hulle maatstawwe die swakker behandeling moet kry.

45 In die geval van die sinagoge was dit ook so - hoe nader aan die podium met die Tora hoe beter. Dit lees ons onder andere in gedeeltes soos Matt 23:6, Mark 12:39 en Luk 11:43; 20:46 waar verhaal word hoe die skynheilige Fariseërs die voorste sitplekke uitsoek - dit hang met die soeke na waardigheid en eer saam, soos in die gedeeltes gesê word.
}

46 Dit het darem nie net bloot oor sy kleredrag gegaan nie. Daar was meer op die spel. Rykdom en armoede het sosiale posisie en mag in die anticke wêreld bepaal. Dit gaan dus ook hier om die spel rondom sosiale mag en invloed. Met hulle gedrag probeer die gemeente die aardse invloed van die ryke verdien. Die strekking van Jak.2:5 en verder toon aan dat hulle 'n oordeelsfout maak - die mense met die mag is die mense met wat deel van God se koninkryk is.

47 Die plek waar eer en skande toegeken of weggeneem is, is in die openbare oog. 
die arme oneer aangedoen. Dit kom neer op die perspektief waarmee daar na die gebeure in hierdie wêreld gekyk word. 'n Mens kan deur die oë en met die wysheid van 'n mens kyk - dan sien jy aardse rykdom en status raak; maar 'n mens kan ook deur die oë en met die wysheid van God kyk - dan lyk mense en wat hulle doen vir jou anders (kyk Jak 3:13-18). Dit is wat daar na alle waarskynlikheid bedoel word met die woorde: "Het julle nie dan mense op grond van verkeerde oorwegings beoordeel nie?" (Jak 2:4).

\section{Literatuurverwysings}

Adamson, J B 1976. The Epistle of James. Grand Rapids: Eerdmans.

Boggen, C W 1982. Wealth in the Epistle of James. PhD dissertation, The Southern Baptist Theological Seminary.

Botha, P J J 1998. Houses in the world of Jesus. Neotestamentica 32(1), 37-74.

Bühlmann, W 1994. Wie Jesus lebte. Luzern: Rex.

Cedar, P A 1984. James, 1,2 Peter, Jude. Waco: Word.

Connolly, P \& Dodge, H 1998. Die antike Stadt. Köln: Könemann.

Davids, P H 1982. The Epistle of James. Exeter: Paternoster.

Dibelius, M 1964. Der Brief des Jakobus, 11: Auflage, Herausgegeben und ergänzt von $H$ Greeven. Göttingen: Vandenhoeck \& Ruprecht.

Du Plessis, P J 1993. Jakobus, in Die Bybel verklaar. Kaapstad: Lux Verbi. (Lux Verbi Library op Logos online.)

Feinberg, C L 1998. Synagogue, in Bruce, F F (ed), New Bible Dictionary. London: InterVarsity Press. (London op Logos online.)

Felder, C H 1982. Wisdom, law and social concern in the Epistle of James. PhD dissertation, Columbia University.

- 1982-83. Partiality and God's law: An exegesis of James 2:1-13. The Journal of Religious Thought 39(2), 51-69.

Gispen, W H, Oosterhoff, B J, Ridderbos, H N, van Unnik, W C, Visser, P 1997. Sinagoge, in Bybelse Ensiklopedie. Kaapstad: Verenigde Protestantse Uitgewers. (Lux Verbi Library op Logos online.)

Grosheide, F W 1970. De Brief van Jakobus: Opnieuw uit de grondtekst vertaald en verklaard. Kampen: Kok. 
Grünzweig, F 1978. Der Brief des Jakobus. Wuppertal: Brockhaus.

Hachlili, R 1992. Synagogue (Diaspora synagogue), in Freedman, D N (ed), The Anchor Bible Dictionary. New York: Doubleday. (New York op Logos online.)

Hoppe, R 1989. Jakobusbrief. Stuttgart: Katholisches Bibelwerk.

Kee, H C 1995. Defining the first-century CE synagogue: Problems and progress. NTS 41, 481-500.

Laws, S 1980. A commentary on the Epistle of James. London: Black.

Louw, J P \& Nida, E A 1988-1989. Greek-English Lexicon of the New Testament based on Semantic Domains. New York: UBS.

Maier, G \& Holland, M 1988. Jakobusbrief, Judasbrief. Stuttgart: Hänssler.

Malina, B J \& Rohrbaugh R L 1992. Social-Science commentary on the Synoptic Gospels. Minneapolis: Fortress.

Maynard-Reid, P U 1987. Poverty and wealth in James. New York: Orbis.

Martin, R P 1988. James. Dallas: Word.

McKeever 1995. Ancient Rome. London: Puffin.

Meyers, E M 1992. Synagogue (Introductory survey), Freedman, D N (ed), in The Anchor Bible Dictionary. New York: Doubleday. (New York op Logos online.)

Mußner, F 1981. Der Jakobusbrief. Freiburg: Herder.

Neyrey, J H 1998. Honor and shame in the Gospel of Matthew. Louisville, KT: Westminster.

Penner, T C 1996. The Epistle of James and eschatology: Rereading an ancient Christian letter. Sheffield: Sheffield Academic Press.

Phifer, K G 1982. James 2:1-5. Interpretation 37(3), 278-282.

Polhill, J B 1986. Prejudice, partiality and faith: James 2. Review and Expositor 83, 395404.

Pretorius, E A C 1988. Die Brief van Jakobus. Kaapstad: NG Kerk-Uitgewers. (Lux Verbi Library op Logos online.)

Reike, B 1964. The Epistles of James, Peter and Jude. New York: Doubleday.

Rousseau, J J \& Arav, R 1996. Jesus and his world. London: SCM.

Schlatter, A 1956. Der Brief des Jakobus. Stuttgart: Calwer.

Schnider, F 1987. Der Jakobusbrief. Regensburg: Pustet. 
Setzer, C J 1992. Rulers of the Synagogue, in Freedman, D N (ed), The Anchor Bible Dictionary. New York: Doubleday. (New York op Logos online.)

Sidebottom, E M 1982. James, Jude, 2 Peter. Grand Rapids: Eerdmans.

Smelik, E L 1960. De Stiefapostel: De Brief van Jakobus. Nijkerk: Callenbach.

Smit, D E 1990. Exegesis and proclamation: "Show no partiality ..." (James 2:1-13). Journal of Theology for Southern Africa 71, 59-68.

Vyhmeister, N J 1995. The rich man in James 2: Does ancient patronage illumine the text? Andrews University Seminary Studies 33(2), 265-283.

Wall, R W 1997. Community of the wise. Philadelphia, PA: Trinity Press International.

Ward, R B 1969. Partiality in the assembly: James 2:2-4. HTR 62, 87-97.

Williams, R R 1965. The letters of John and James. Cambridge: CUP. 


\section{Addendum}

- Die volgende figuur (figuur 1) toon aan hoe die bankies langs die mure afgeloop het. Die arm man was dan veronderstel om heel onder te sit.

Figuur $1^{48}$

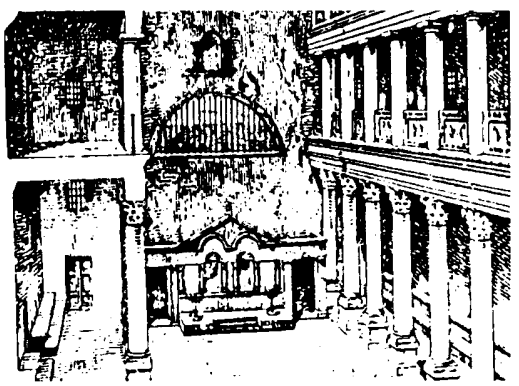

- Hoe 'n tipiese lêbank met die voetstoel gelyk het, blyk uit figuur 2.

Figuur $2^{49}$

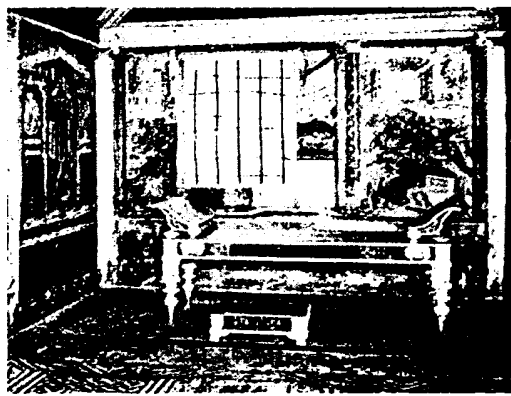

${ }^{48}$ Die illustrasie kom uit Bühlmann (1994:57).

49 Vgl Bühlmann (1994:75); McKeever (1995:53); Connolly en Dodge (1998:149) vir illustrasies van hoe 'n kamer met sulke banke daar uitgesien het. 
- Die vrou in figuur 3 wat deur ander vroue versorg word, sit op 'n rottangstoel met haar voete wat op 'n voetstoel rus.

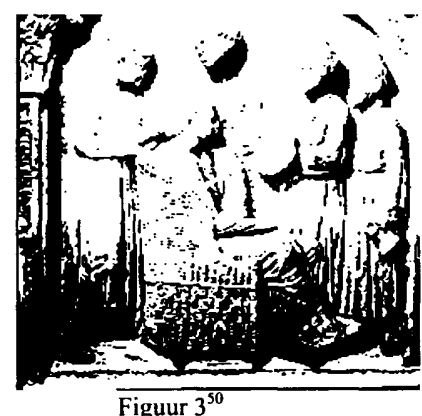

Die aaneenskakeling van die sitkamer met die binneplein kan in die meegaande illustrasie goed gesien word. Die plan van die huis wys ook hoe die kamers op die binneplein uitloop. Die binneplein is 2 gemerk en die sitkamer 1 - die twee kamers is in die boonste illustrasie uitgebeeld.
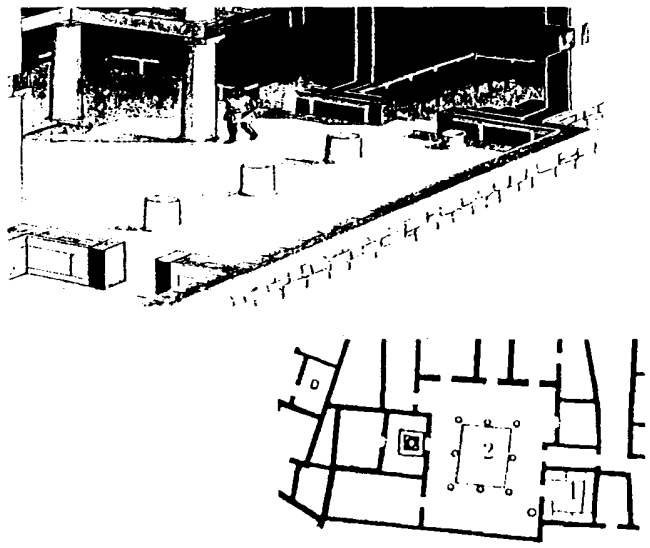

Figuur $4^{51}$

\footnotetext{
${ }^{50}$ Hierdie is ' $n$ Romeinse reliêf uit Neumagen. Dit is op die oomblik in die museum in Trier (vgl Connolly en Dodge 1998:158).

5) Die illustrasies kom uit Connolly en Dodge (1998:51).
} 
- Figuur 5 bevat 'n illustrasie van 'n "troshuis". Daar kan duidelik gesien word hoe die verskillende kamers om die binneplein gebou is.

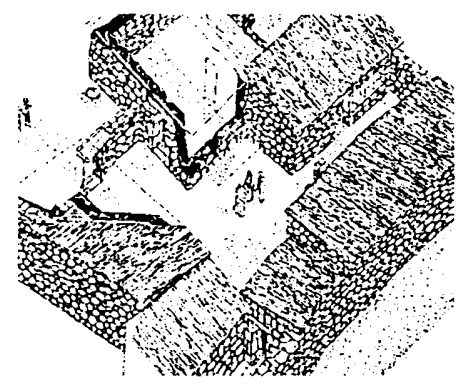

Figuur $5^{52}$

- Figuur 6 bevat 'n plan van 'n tipiese huis. Die sentrale posisie van die binneplein blyk duidelik.

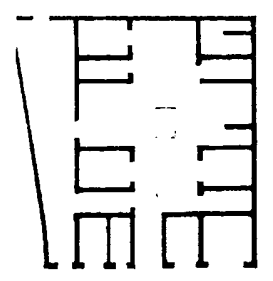

Figuur $6^{53}$

\footnotetext{
${ }^{52}$ Die illustrasie kom uit Bühlmann (1994:55) en toon 'n huis uit "wooneiland II" in Kapernaum.

${ }^{53}$ Die illustrasie kom uit Connolly en Dodge (1998:134).
} 